\title{
CASSIRER E SARTRE SOBRE O ESCLARECIMENTO
}

\author{
Vinicius de Figueiredo* \\ viniciusbf@yahoo.fr.
}

RESUMO O presente ensaio levanta alguns aspectos da estética no século XVIII. Partindo da apresentação de duas interpretações hoje clássicas sobre o assunto (a de Cassirer e a de Sartre), busca rever o pressuposto analítico comum a ambas, para, em seguida, apontar as conseqüências que a relação entre autor e público trazem para a compreensão de aspectos estilísticos que nos parecem centrais para a literatura do Esclarecimento.

Palavras-chave Cassirer, Sartre, Iluminismo, Público, Autor

ABSTRACT This paper aims at throwing some light on the EighteenthCentury aesthetics. After examining two classical interpretations - Cassirer e Sartre's - concerning this subject, I argue that both authors share a common analytical pressupposition. My main purpose is to show that without taking account of the the relationship between author and public, we cannot understand some essential characteristics of the literature in the Enlightenment.

Keywords Cassirer, Sartre, Enlightenment, Public, Author

* Departamento de Filosofia da Universidade Federal do Paraná/CNPq. Artigo recebido em 15/09/05 e aprovado em 15/11/05.

KRITERION, Belo Horizonte, n 112, Dez/2005, p. 199-213 


\section{I - Cassirer e a interpretação do século XVIII como descoberta do gosto}

No "Prefácio" de seu A filosofia do Iluminismo, ${ }^{1}$ Ernst Cassirer reivindica para a intelligentsia do século XVIII uma contribuição cuja originalidade reside não tanto nos conteúdos por ela propostos, mas na maneira pela qual conteúdos herdados da tradição foram abordados. Deste ponto de vista, o sentido "verdadeiramente fecundo" do pensamento das Luzes "manifesta-se menos por um conteúdo do que pelo próprio uso que faz do pensamento filosófico, pelo lugar que lhe confere e pelas tarefas que lhe atribui" ${ }^{2}$. Daí por que Cassirer insista em voltar nossa atenção para a atitude que, sob a diversidade dos campos tematizados pelos iluministas, presidiria o período e que ele resume na idéia motriz da "autonomia da Razão", efetuada em "todos os domínios da vida e do

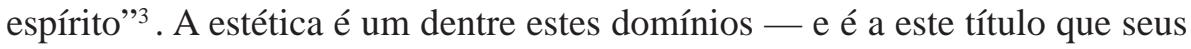
"problemas fundamentais" são expostos na $3^{\mathrm{a}}$ e na última partes de A filosofia do Iluminismo.

Tal como é de se esperar, Cassirer aí irá expor os motivos que nos autorizam a reencontrar, no regime das questões vinculadas à produção artística e literária, a efetuação do ideal esclarecido, a saber, sua aposta na "espontaneidade originária do pensamento". ${ }^{4}$ Embora admitam diversas manifestações, esses motivos convergem para um mesmo ponto de fuga, representado pela consciência inédita da dignidade filosófica do sensível. ${ }^{5}$ Ao afirmar que o século XVIII marca o advento da estética a título de disciplina autônoma que tematiza o sensível enquanto tal, Cassirer vincula sua interpretação da inovação do Iluminismo no campo da arte e da literatura a um juízo nada complacente acerca da "estética" que precede imediatamente ao século XVIII — a ponto de podermos até nos perguntar se, uma vez subscrita a tese de Cassirer, tal título de fato convém à reflexão sobre a arte e a literatura seiscentistas. Pois seria

\footnotetext{
CASSIRER. A filosofia do lluminismo, p. 7-16.

5 "Reencontramos o mesmo processo em todos os esforços, tão diversos e tão divergentes, efetuados no século XVIII para a fundação da estética: ele foi seu centro de gravidade latente, o seu foco espiritual. É evidente que entre os numerosos pensadores que participaram nesse movimento, nenhum deles tem, no início, a menor consciência do objetivo para o qual ele tende, nenhum reconhece de imediato uma linha determinada à qual o curso do pensamento ligar-se-ia, um problema básico nitidamente concebido e conscientemente visado no conflito das múltiplas correntes. A problemática, pelo contrário, mantém-se em permanente movimento e, segundo o predomínio deste ou daquele interesse - psicológico, lógico, ético -, assiste-se a um perpétuo deslocamento de sentido das normas e dos conceitos fundamentais que governam a estética nascente. Mas, no final, cristaliza-se, a partir desse complexo de tendências de aparência contraditória, uma nova configuração" (Ibidem, p. 369-370).
} 
legítimo designá-la por esse termo, se é verdade que, antes do século XVIII, o sensível tem sua temática ignorada e, como quer Cassirer, inteiramente subordinada ao conhecimento intelectual?

Antes de esboçar por nossa conta e risco uma resposta a esta questão, e apresentar eventuais ressalvas à interpretação de Cassirer, tratemos de comentála um pouco mais. Pelo que se depreeende do que já foi dito, fica claro que nosso intérprete vê nas Luzes a progressiva emancipação do sensível em relação ao intelectual, o gradual reconhecimento de que o sensível dispõe de uma dinâmica própria - a ponto de se poder falar do advento de uma nova problemática, irredutível à questão do conhecimento ou da moral. Não faltam textos que, à primeira vista, confirmam esta leitura. É assim que, em 1750, Baumgarten define a estética como "ciência do conhecimento sensitivo", o que requer a admissão de que, ao lado da perfeição representada pelo conhecimento intelectual, único capaz de distinção, há uma perfeição de outra ordem, que recobre o território do belo. Contra a tradição intelectualista da filosofia seiscentista, que enxergava no sensível o lugar da fala confusa, a ser vertida na distinção própria aos conceitos do intelecto, Baumgarten institui a idéia de uma "perfeição estética" - delimitando o terreno sobre o qual a abordagem ao belo irá agora comportar o estatuto de uma Wissenschaft. ${ }^{6}$ Essa inovação, já o sabemos, Cassirer não a vê como um fato isolado, e sim como a variante da atitude que o Iluminismo tem diante da arte e da literatura. Na sua direção já apontava a defesa que, do interior do classicismo francês, Bouhours (1628-1702), polemizando com os jansenistas, fazia do estilo. ${ }^{7}$ Antecipando a idéia de "ilusão estética", que prefigura a emancipação do belo frente ao verdadeiro, Bouhours fornecia as condições para a edificação da "estética do sentimento", que será elaborada por Du Bos na metade do século XVIII (Réflexions critiques sur la poésie et la peinture, 1755). ${ }^{8}$ Idêntica tendência verificaríamos no debate anglo-saxão, no interior do qual Cassirer traça um fio de continuidade que, de Shaftesbury a Hume, passando por Francis

6 BAUMGARTEN. Aesthetica. In: Estética - A lógica da arte do poema, §1, §14 e §17. Para o comentário de CASSIRER, ver: A filosofia do lluminismo, p. 444.

7 "É a expressão, não o conteúdo do pensamento como tal, que contém cada vez mais a verdadeira carga estética. Não é surpreendente, portanto, e muito menos paradoxal, nesse contexto, que Bouhours exija para todo produto válido da arte não a verdade pura e simples, mas uma certa mistura expressa de falsidade, e que por essa mesma razão justifique o equívoco, porque o falso e o verdadeiro aí estão misturados e formam uma unidade" (CASSIRER. A filosofia do lluminismo, p. 399).

8 Du Bos, segundo Cassirer, radicaliza, assim, a independência do estético diante do teórico: "A essência da estética não pode ser conhecida de maneira puramente conceitual; o teórico, nesse domínio, não dispõe de outros meios para comunicar suas intuições de um modo convincente a não ser recorrendo à sua própria experiência interior" (A filosofia do lluminismo, p. 401). 
Hutcheson e Edmund Burke, consolida a concepção de que o elemento principal na obra literária ou artística não é a imitação, mas o ato de criação — cujos aspectos subjetivos, ao ocuparem o centro da análise, propiciam a elaboração de uma estética do sublime e do gênio que subverte o caráter prescritivo da "estética" seiscentista."

A crer em Cassirer, portanto, ao longo do século XVIII, assistimos a esforços diversos que tendem, todos, para a "fundação da estética". Disso, o Iluminismo fez "seu centro de gravidade latente, o seu foco espiritual". ${ }^{10}$ No cômputo geral, não é pouco: essa “"humanização” da sensibilidade”, como a designa Cassirer, ${ }^{11}$ inscreve a instituição da temática própria ao sensível no movimento da aceitação da finitude do homem — pois é por meio de sua sensibilidade que o homem, distinguindo-se do infinito, adquire sua marca específica. "Desde que a fundação da estética teórica sustenta a causa da autonomia do belo, ela anuncia implicitamente, desse modo, que a natureza finita tem fundamentalmente direito ao seu modo de ser autônomo". ${ }^{12} \mathrm{Ou}$ seja: o significado mais amplo da fundação da estética no século XVIII está em que este fato vale como certidão de nascimento da idéia de homem. O projeto de uma antropologia filosófica, desenvolvida por Cassirer em outros textos, vêse, desse modo, avalizado pela leitura que faz da estética setecentista.

Com isso, em contrapartida, vai se tornando clara a outra face do elogio de Cassirer ao Iluminismo. Se foi mesmo preciso esperar pelo século XVIII para que o sensível tivesse sua dignidade filosófica reconhecida, então, será forçoso concluir, o classicismo francês, a rigor, não foi, nem poderia ter sido uma estética. Confirma-o o que diz Cassirer de alguns de seus principais representantes — D' Aubignac (Pratique du théâtre, 1657), Boileau (Art poétique, 1674), Batteux (Les beaux arts réduits à un même principe, 1747). Afirmando que neles o belo se vê subordinado a fins exteriores, vinculados sobretudo à descoberta da verdade, Cassirer conclui que a real significação do sensível lhes permaneceu oculta. A atribuição deste caráter deficitário ao classicismo - ele não é uma estética, pois não reconhece o sensível — apóiase na caracterização deste último como conjunto de prescrições ao artista, cuja imaginação é domesticada e subordinada a uma intenção edificante; como se isso não bastasse, as "regras" alimentam o desprezo pelo singular e individual em prol de ideais universais e atemporais. Avessa ao gosto, cujo exercício

9 CASSIRER. A filosofia do lluminismo, p. 419-433.

10 Ibidem, p. 369.

11 Ibidem, p. 459.

12 Ibidem, p. 458. 
requer o livre desenvolvimento da subjetividade, a mimesis clássica é, aos olhos de Cassirer, refém de seu compromisso com a exposição da verdade; enquanto permanecer válida, "a imaginação do poeta deve ser guiada e controlada pela razão e sujeita às regras desta". ${ }^{13}$

Como se depreende daí, Cassirer propõe-nos interpretações complementares do classicismo e do Iluminismo, a passagem entre eles obedecendo à lógica da descoberta. A hipótese de que o século XVII dispunha de uma estética própria, pautada por parâmetros irredutíveis àqueles que irão guiar a reflexão sobre a literatura e a arte no século XVIII não entra na pauta. A leitura de Cassirer formula-se em uma intuição diversa: o classicismo permaneceu cego para tudo aquilo que será trazido à luz pelo Iluminismo. $\mathrm{O}$ homem já estava lá, aguardando um "espírito de época" capaz de reconhecer sua proximidade incógnita, sua presença secreta, da qual é parte constitutiva o sensível e as variantes em que ele se manifesta no século XVIII — as paixões, o sentimento, a imaginação livre de intentos cognitivos, o gênio.

Em que medida Cassirer considera a época clássica ter sido incapaz deste reconhecimento da estética é o que fica claro, tão logo o seguimos em sua digressão sobre os vínculos essenciais que, a seu ver, ligam o classicismo à filosofia cartesiana. A dependência do belo em relação ao verdadeiro, no século XVII, responderia à exigência de que a arte seja conforme à razão e, nesta medida, pautada pelo ideal da verdade. Esta adequação revelaria a primazia exercida pelo "espírito do cartesianismo" em todos os domínios da vida espiritual seiscentista. ${ }^{14}$ Daí por que Cassirer explique as diretrizes da mimesis clássica como resultados da transposição do cartesianismo para o âmbito da reflexão sobre a literatura e a arte. O ideal de unidade propugnado por Descartes estaria, desse modo, na origem do esforço do classicismo em reduzir a diversidade poética a princípios formuláveis no corpo de uma teoria; a irrelevância da dimensão criadora e do juízo subjetivo para a mimesis clássica explicando-se, igualmente, pelo fato de que, no cartesianismo, todo elemento subjetivo é direcionado para a descoberta da verdade.

Intentar aqui nossa própria reconstrução do classicismo nos desviaria de nosso objetivo, bem mais modesto. Porém, a fim de propor uma aproximação da originalidade da estética do século XVIII, é preciso reaver, mesmo que apenas na forma da polêmica com Cassirer, aqueles que nos parecem ser os

13 CASSIRER. Ensaio sobre o homem, p. 249. Ver também: A filosofia do lluminismo, p. 371-394.

14 CASSIRER. A filosofia do lluminismo, p. 372. Para a noção de época enquanto sistema de valores, ver do mesmo autor, Descartes, Corneille, Christine de Suède e, sobretudo, Das Erkenntnisproblem in der Philosophie und Wissenschaft der neueren Zeit, in: Gesammelte Werke, v. II. 
termos adequados à formulação da passagem do classicismo às Luzes sobretudo porque, a nosso ver, esses termos não giram em torno do progresso que teria sido representado pela descoberta da autonomia da sensibilidade e, no plano mais abrangente, pela descoberta do homem. É inegável que o classicismo se apóia em um conjunto de regras que pautam a produção da obra, assim como também é inquestionável que, em função disso, a imaginação se vê subordinada a uma disciplina rígida, que inibe o desvio e coopta o autor a formas instituídas previamente no cânone. Tampouco se pode negar a interdição ao burlesco e ao estilo afetado, presentes como orientação normativa geral do classicismo francês, e justificada com base no compromisso da arte com a imitação da natureza. Ocorre apenas que nenhum destes elementos faz do classicismo uma teoria cujo significado último teríamos de buscar no cartesianismo. Para dirimir qualquer suspeita a esse propósito, basta evocar por contra-exemplo ao esquema interpretativo de Cassirer a poética horaciana, na qual cada gênero literário demarca um domínio e define um tom próprio, exigindo do artista um estudo que o habilita a adequar-se a preceitos instituídos de antemão. "Guarde cada gênero o lugar que lhe coube e lhe assenta". ${ }^{15}$ Horácio não se baseou em Descartes para proferir essa máxima, nem a instituição de uma estética prescritiva, por si mesma, acarreta necessariamente o compromisso da mimesis com a objetividade do saber. A rigor, não há nenhuma incompatibilidade de origem entre a existência de um conjunto de preceitos e a incidência de um certo gosto,${ }^{16}$ desde que o compreendamos como categoria pautada por diretrizes diversas do gosto iluminista. Cassirer descarta de antemão esta correlação entre prescrição e beleza (presente na poética antiga e retomada pelo classicismo francês) por partir da idéia de que, substancialmente, a inteligibilidade da literatura e da arte é inseparável da história da filosofia. Daí por que veja nos elementos prescritivos efetivamente presentes no classicismo francês o resultado de um "preconceito objetivista", fruto da transposição do cartesianismo para os âmbitos da arte e da literatura, em vez de uma escolha estilística fundada em razões que pouco ou nada devem à filosofia.

\section{II - Sartre e a importância do público}

A lição a tirar deste confronto mínimo com Cassirer resume-se a isto: em vez de procurarmos explicar a existência de uma teoria da mimesis, no século XVII, pela subordinação do classicismo a questões de ordem metafísica, convém

15 HORÁCIO. Arte poética, in: A poética clássica, p. 57.

16 O termo comparece em Horácio, "Arte poétic", op. cit., p. 61. 
examinar se o compromisso estilístico firmado aí não tem razões de outra ordem. Sabe-se que a vigência de um corpo de regras ou máximas pautando a criação artística e literária supõe, na outra ponta da relação simbólica subjacente à obra, um público cujo juízo depende de sua competência com os mesmos preceitos que presidem a criação, e com base nos quais ele interpreta esta e aquela obra particulares. ${ }^{17}$ Nesse contexto, a "teoria", subordinando o ingenium a uma disciplina, habilita o escritor a inscrever sua obra no contexto normativo representado por um repertório de máximas partilháveis publicamente. A domesticação do gênio por meio da expectativa oriunda do gênero ao qual se dedica revela, por isso, uma dimensão mais sociológica que metafísica: a hierarquia dos gêneros e o ideal de se adequar a eles atesta a existência de um circuito ligando autor e público de maneira recíproca. Eis um elemento importante para sustentar que a "objetividade" perseguida pela mimesis clássica deve pouco, e de modo indireto, ao ideal da ciência seiscentista, antes exprimindo a força das regras na sociedade cortesã — hipótese que restitui a nossa questão sua natureza estilística (entendida por oposição a sua natureza especulativa), além de aventar nova interpretação para o que virá a seguir. Com efeito, ao longo do século XVIII, o que mais assistimos senão à quebra desta reciprocidade, vigente no classicismo, entre autor e público — ruptura esta que, no limiar do romantismo, tornará possível ao autor criar, no plano da ficção, seu próprio público?

Formulada como está aqui neste grau de generalidade, esta hipótese prestase deliberadamente a propósitos esquemáticos, pondo de lado deslocamentos transcorridos no interior do próprio classicismo, os quais, fique registrado, são relevantes para o problema em pauta. ${ }^{18}$ Interessa-nos agora estabelecer o contraste. Nesta direção, vão as observações de Sartre acerca do classicismo:

17 "Antes de situar-se em horizontes críticos, retóricos e filosóficos, o tema do gosto, nos séculos XVI e XVII franceses, é uma questão social, que se reporta à vida de corte, ou, de modo mais geral, à capacidade do homem culto e refinado de construir uma 'arte da conversação' que tenha seu norte no gosto" (FRANZINI. Il gusto in Francia dal Gran Secolo alla Rivoluzione. In: RUSSO (Org.). I/ gusto - Storia di uma idea estetica, p. 35.

18 A referência ao cânone é um fator recorrente na poética clássica francesa, tendo servido a todo tipo de polêmica. É o que ilustra, por exemplo, o fato de que o recurso às regras se prestou a combater Corneille, na polêmica do Cid, e, adiante, foi visto como obstáculo ao reconhecimento da grandeza de Racine diante de Corneille. Leia-se, a propósito, o que diz, no início da década de 1660, um espectador de Bérénice: "Je veux grand mal à ces règles, et je sais fort mauvais gré à Corneille de me les avoir apprises dans ce que j' ai vu Bérénice à l' Hôtel de Bourgogne du plaisir qu' y prenaient ceux qui ne les savaient pas: mais je me suis ravisé le second jour, j' ai attrapé M. Corneille, j' ai laissé Mesdemoiselles les règles à la porte, j' ai vu la comédie, je l' ai trouvée fort affligeante et j' ai pleuré comme un ignorant" (Montfaucon de Villars, "La Critique de Bérénice", apud: RACINE. Théâtre complet - I, p. 514. Racine, na carta a Colbert que prefacia Bérénice, resume bem o ponto em pauta: "La principale règle est de plaire et de toucher" (RACINE. Théâtre complet - I, p. 375). Para a dimensão "modernista" do Cid, analisada em ligação com a disputa entre os doutos e o público, ver MACCHIA. II paradiso della ragione, p. 48 et seq. 
O público é ativo: as produções do espírito são realmente submetidas a ele; ele as julga conforme uma tábua de valores que ele contribui para manter. Uma revolução análoga ao romantismo não é sequer concebível à época, pois ela requer o concurso de uma massa indecisa que surpreendemos, subvertemos, que estimulamos repentinamente revelando-lhe idéias ou sentimentos que ela ignorava e que, na falta de convicções firmes, pede que a violemos e fecundemos perpetuamente. No século XVII, as convicções são intocáveis: a ideologia religiosa duplicou-se em uma ideologia política que foi produzida pelo próprio poder temporal; ninguém põe em dúvida publicamente a existência de Deus, nem o direito divino do monarca. A "sociedade" possui sua linguagem, suas graças, suas cerimônias, que ela presume reencontrar nos livros que lê..$^{19}$

Como se depreende desse trecho, a orientação materialista da análise de Sartre fornece elementos decisivos para interpretarmos a virada do classicismo ao Iluminismo como passagem de uma estética à outra ${ }^{20}$ - e não mais, como sugeria Cassirer, passagem de uma doutrina do belo, no século XVII, ao advento da estética, no século XVIII.

Todavia, na análise de Sartre, estas indicações logo se tornam outra vez desfavoráveis aos escritores (e também aos artistas, aqui em segundo plano) da época clássica. "Alimentados pelo rei, lidos por uma elite, eles preocupamse apenas em responder à demanda deste público restrito". ${ }^{21}$ Por mantê-los sob um "controle permanente", o público clássico, anota Sartre, exerce seu gosto como "censura". ${ }^{22}$ Sem dúvida; mas esta verdade acerca da estética do século XVII, que nos incita a formular, retomando a intuição de Sartre, o princípio da reciprocidade entre autor e público, inflete, na interpretação deste último, em juízo de valor sobre o escritor enquanto tal. Com efeito, o classicismo é arrolado por ele como exemplo da situação do escritor cuja função não é mais a de ser o guardião dos dogmas sociais, como na Idade Média, mas apenas de não criticá-los. ${ }^{23}$ Daí à má consciência do escritor, o passo é previsível. E assim prossegue Sartre. O autor clássico, aderindo à ideologia constituída, não guarda nenhum recuo diante do ideal dirigente do honnête homme, abrindo mão do que Sartre crê ser essencial ao ato de escrever: a produção da Alteridade desde o interior de sua relação com o público efetivo. ${ }^{24}$

19 SARTRE. Qu'est-ce la littérature, p. 112.

20 R. Zuber, nesta linha, fala em um gosto clássico (La littérature française du XVIle siècle, p. 58).

21 SARTRE. Qu'est-ce la littérature, p. 114.

22 A idéia, por mais que pertença à classe de intuições de Sartre sobre literatura, é relativamente consensual. G. Highet, por exemplo, também observava, em 1949, que "as convenções barrocas eram restrições sociais. Escrever uma boa obra teatral é criar uma obra de arte. Manter o decoro - as bienséances - é conformarse a um código social aristocrático. O dramaturgo barroco tinha de fazer ambas as coisas" (HIGHET. La tradición classica, p. 21.

23 SARTRE. Qu'est-ce la littérature, p. 110.

24 Ibidem, p. 96. 
Desse modo, aquilo que parecia representar uma perspectiva vantajosa no cotejo inicial com Cassirer mostra-se, em verdade, um ganho relativo, pois o que, na incursão de Sartre, se assemelhava a uma aproximação da especificidade da mimesis clássica e, portanto, do gosto que lhe é próprio, redunda, assim como ocorre em Cassirer, como juízo retrospectivo. Cobra-se do escritor do século XVII um engajamento que, por vezes, o próprio Sartre reconhece ser irrealizável, porque extemporâneo. "Nesta época, é impossível mencionar um público virtual distinto do público real". ${ }^{25}$ Eis o autor clássico eximido de sua culpa, mas isso ao preço de concluirmos que a estruturação social de sua função, à época, constitui por princípio um obstáculo incontornável ao exercício de seu ofício, definido previamente por Sartre a partir de condições que só irão se apresentar adiante, no século XVIII. O resultado é esta alternativa desconcertante: ou o autor clássico age com má consciência, ou, na melhor das hipóteses, não é sequer escritor, por ser incapaz de projetar no universo literário as exigências simbólicas requeridas para a transformação política da sociedade.

Nada disso desmerece as análises propostas em $O$ que é a literatura, nem, tampouco, lhes destitui de valor e interesse para os fins propostos neste ensaio. Ao contrário, o ponto que nos parece questionável na interpretação de Sartre é de enorme utilidade para precisar nosso problema, bastando inverter os termos que ele põe em circulação. Com base na convicção de que o escritor se define por seu engajamento na transformação política da sociedade e na constatação de que, no classicismo, a relação entre o escritor e o público impede este engajamento, Sartre conclui pela impossibilidade da autêntica literatura no século XVII. Na direção contrária, examinemos se não foi a mudança na relação entre autor e público transcorrida no século XVIII, representada pela quebra de reciprocidade entre eles, o que (dentre outros fatores) não tornou possível que o escritor, no Iluminismo, adotasse esse compromisso com a instituição fictícia de uma sociedade diversa daquela efetiva - a marca genuína do escritor engajado em transformar politicamente a sociedade. Nisto exprime-se, então, nossa divergência com Sartre: em lugar de dizer que no classicismo o apelo à Alteridade está interditado, diremos que ele carece de sentido no sistema social que lhe corresponde. ${ }^{26} \mathrm{E}$ isso porque a conversão do destinatário da obra no

25 SARTRE. Qu'est-ce la littérature, p. 115.

26 "Época da eloqüência, época da retórica, o século XVII vê nascer as Belas-Letras: ele não é, por ora, a época da literatura" (FUMAROLI. L'âge de l'éloquence, p. 31. Note-se, do ponto de vista sociológico, que a exclusão da Alteridade não era infortúnio dos escritores, nem dos excluídos da corte; como bem mostrou N. Elias, nem mesmo Luis XIV podia ser diverso do que se esperava dele no interior do código cortesão. Ver: ELIAS. La sociedad cortesana, p. 184 et seq. 
"leitor universal", no "público virtual" mencionado por Sartre, depende do advento de um público burguês, que, inexistente no século XVII, se tornará uma realidade no século seguinte.

Precavidos quanto aos riscos de uma eventual retrospecção, procuremos, então, imaginar a alteração por que passa a estética literária, uma vez transcorridas as mudanças na composição social do público. $\mathrm{O}$ fenômeno que mais facilmente nos permite medir a magnitude deste deslocamento ocorreu na Inglaterra da primeira metade do século XVIII. Como é sabido, foi o advento do público burguês que tornou possível o aparecimento de uma forma literária popular como o romance. Swift, Richardson, Defoe e Fielding foram autores de obras cuja universalidade ultrapassou qualquer outra obra da época. ${ }^{27}$ Ian Watt, em sua clássica interpretação da ascensão do romance, fala em alteração do "centro de gravidade do público leitor", quando a classe média adquire nele posição predominante. ${ }^{28}$ Heróis do novo gênero, como Robinson Crusoe e Moll Flanders, observa Watt, "situam-se no plano moral da vida cotidiana", ${ }^{29}$ permitindo ao leitor comum transportar-se para a situação vivida por eles.

Interessa-nos que, ao comentar este nivelamento do plano ficcional à realidade social do novo público leitor, Watt fornece indicações preciosas para o problema que estamos examinando. Pois a "humanização" das personagens e do enredo - um traço "realista" do romance, que, assim, inova frente à mimesis clássica - é a contrapartida de uma alteração paralela, relativa às funções que o público deixa de exercer sobre a obra literária. Sua fruição, agora, dispensa a familiaridade com o repertório de preceitos e sua referência à tradição clássica, aproximando-se do tipo de leitura "desatenta, quase inconsciente" da outra nova forma literária rapidamente difundida na época, o jornal. ${ }^{30} \mathrm{O}$ leitor corresponde a uma nova figura, diversa do honnête homme: ele não quer exercer uma função de controle sobre o autor, nem, tampouco, estaria apto a fazê-lo, como ocorria no classicismo. Daí por que a clareza perseguida estilisticamente por um romancista como Defoe nada tenha que ver com a simplicidade visada pela mimesis clássica, a começar porque, agora, ela se associa a procedimentos de simplificação ${ }^{31}$ que asseguram um tipo de fruição avesso à competência crítica do público de corte.

27 HUMPHREYS. The Literary Scene. In: FORD (Ed.). The New Pelican Guide to English Literature: From Dryden to Johnson, p. 53-98.

28 WATT. A ascensão do romance, p. 44.

29 Ibidem, p. 71.

$30 \mathrm{Ibidem}$, p. 45. Como é sabido, esse aspecto do público leitor, constatado por Sartre e por Watt, foi largamente retomado pelos estudiosos da repceção, cujo debate, porém, desloca o foco de nosso presente interesse. Ver, para um apanhado do assunto e das questões de método envolvidas, a "Introdução" de J. S. Allen. In: In the Public Eye - A History of Reading in Modern France, 1800-1940.

31 Daí a completa oposição da simplicidade de enredo e expressão buscada na tragédia francesa, explicitamente 


\section{Conclusão}

Isso basta para concluirmos que inflexões estilísticas se associam à modalidade da relação vigente entre autor e público, reiterando nossa suspeita inicial de que as razões da mimesis de uma época remetem menos à metafísica que supostamente a preside, do que à sociologia que ela comporta. A própria forma literária em grande parte conforma-se a este vínculo, como atesta a ascensão do romance. Resta que o advento do público burguês está na origem de aspectos literários que ultrapassam uma forma literária determinada, como a criada pelos britânicos na primeira metade do século XVIII. À guisa de conclusão, vejamos um aspecto que exemplifica o modo com que o escritor iluminista incorpora, como recurso literário, os elementos trazidos à baila pela mudança na composição social de seu público.

Aludimos ao fato de que, no classicismo, o escritor ou o dramaturgo pauta sua produção tendo em vista o repertório de preceitos e obras a partir do qual seu público especializado exerce juízo e crítica. Sartre aponta a seu modo que, nesse contexto, os escritores "têm por ofício reenviar à elite que os mantém a imagem dela mesma". ${ }^{32}$ Isto é o que formulamos como o princípio da reciprocidade: o controle da produção pela recepção supõe um público não massificado, constituído por indivíduos que convergem em torno de ideais não só estilísticos, mas também, como diz Sartre, de classe. ${ }^{33}$ Que sentido pode haver, no interior desta formação social e da função que nela se destina ao escritor ou dramaturgo, a procura por originalidade? Reivindicações de autenticidade não supõem que a crítica tenha deixado de ser a reiteração idealizada de valores do grupo dirigente e se tornado, por essa operação de descolamento, indeterminada e abstrata, como será o caso do Iluminismo em diante?

A modificação da relação entre público e autor advinda com o aparecimento do leitor burguês, com efeito, promove o advento do escritor original. No classicismo, a liberdade de movimento do autor resumia-se à "direção da expressão e da apresentação" 34 de um conteúdo que, por meio da tradição literária e da divisão dos gêneros, se encontrava em boa parte predeterminado. Daí por que, do lado do público, o leitor ou o espectador definia-se por sua

apoiada nos Antigos, em relação, por exemplo, aos procedimentos digressivos e ao descaso sintático presentes nos romances de D. Defoe. O ponto é discutido por Watt, em A ascenção do romance.

32 SARTRE. Qu'est-ce la littérature, p. 115.

33 Convém ao honnête homme, além da boa companhia e da elegância, a competência na conversação e boas leituras. Ver: FARET, N. L' honnête homme, 1630. Apud ZUBER. La littérature française du XVIle siècle, p. 54.

34 CASSIRER. A filosofia do lluminismo, p. 386. 
capacidade de, por assim dizer, antecipar-se à obra e, reiterando sua inscrição em uma comunidade ideológica restrita, mostrar-se apto a julgar sua adequação a uma escala de valores efetivamente partilhada com os demais integrantes de seu meio social (o grand monde, representado pela corte, cujo caráter público é crucial, como já se observou ${ }^{35}$ ). Daí a crítica amparar-se em instituições dispostas em círculos concêntricos em torno do Rei, junto ao qual a obra tinha seu êxito em boa parte decidido. ${ }^{36}$ Com a nova modulação entre ficção e composição social do público realizada pelo romance, a correspondência entre obra e realidade é renovada no século XVIII, sendo transposta para novos termos com o advento do leitor burguês. O realismo do romance provém do fato de que seu herói é, como o leitor burguês, anônimo. E isso não resume toda história. Pois, do interior do anonimato que caracteriza sua inserção efetiva em uma experiência particular e segmentada, o burguês almeja integrar uma comunidade universal, por cuja idéia responde, nas Luzes (e isso em um âmbito que se estende da literatura à moral), a "Humanidade". O destinatário da obra sofreu uma metamorfose: ele é todo e qualquer leitor que, por trás do cidadão, é um homem dotado de "sentimento", entenda-se: de uma competência natural de discernimento que dispensa o aparato crítico que o honnête homme exercia junto a seus pares na sociedade cortesã. A universalização (relativa, claro) da base social do público não admite mais que a obra se paute por princípios exatos, já se entrevendo nisso o caminho que levará à definição kantiana do gosto como "livre jogo" entre imaginação e entendimento. ${ }^{37}$ Agora, o público, na condição de conjunto de instâncias singulares e autônomas, não pode se antecipar à obra, como a medida antecede o caso; ao contrário, sua inserção em uma comunidade normativa espera e faz apelo a um autor-demiurgo que seja capaz, por força de um dom da natureza, de renovar a vocação à universalidade cega, mas essencial, que une todos em uma mesma humanidade. ${ }^{38}$

Eis-nos, só então, frente ao "público virtual” de que nos falava Sartre: ele é constituído de cada um de nós, com o que supostamente temos de melhor, de mais genuíno, mas também, de mais ignorado. ${ }^{39}$ A literatura de sentimento

35 ELIAS. La sociedad cortesana, p. 77.

36 "La tragédie de Bérénice triompha de toutes les critiques: et la Cour et la Ville se passionnèrent pour elle". NICÉRON, P. Mémoires.... Apud RACINE. Théâtre complet - I, p. 473. Para essa organização concêntrica, ver indicação de ELIAS. La sociedad cortesana, p. 69.

37 "Belo é o que apraz universalmente sem conceito" (KANT. Crítica da faculdade do juízo, p. 64.

38 Consulte-se, a propósito, a bela análise de M. Fumaroli sobre a significação positiva que recebe, a partir da modernidade, a noção de autoria, em L'âge de l'éloquence, 25.

39 A ignorância de si, nesta vertente da estética iluminista, presta-se a critério de legitimidade, em uma fórmula cujo exagero revela o paradoxo da nova sensibilidade: quanto menos sei dizer porque a obra me agrada, 
retira daí sua possibilidade, e Cassirer tem razão ao associá-la à "descoberta" que o Iluminismo fez do homem. No nível da análise, porém, guardemo-nos de atrelar esse processo a um progresso de época representado pelo abandono do classicismo em prol da idade da crítica - e isso ainda que sua figura central, a humanidade do homem, enseje tal retrospecção, por vezes subjacente à constatação de que o século XVIII assistiu ao nascimento da estética. Precavidos dela, ganharemos outros horizontes de pesquisa. Por exemplo, por que não examinar se não há uma cumplicidade de forma - aqui pensada em seu imbricamento com a forma social - existente entre o romance realista e a literatura romântica que dá seus primeiros passos na segunda metade do século XVIII? Nos dois casos, o autor se endereça a um público cuja identificação com o plano ficcional comporta uma dualidade de base: somos convocados ora pelo retrato da vida ordinária típica do mundo burguês, cujo heroísmo era preciso literalmente inventar em termos alheios às categorias do classicismo, ora pela inserção em uma comunidade de origem, cuja falta de apoio na realidade justifica o advento do autor extemporâneo, capaz de personalizar, por contraste com o leitor, a dimensão utópica da crítica.

Esses dois aspectos correspondem a tendências que se desenvolveram ao longo do Esclarecimento, e não seria difícil mostrar que muitos textos dramatúrgicos, panfletos políticos, escritos morais e meditações especulativas compartilham, no século XVIII, dessa mesma sensibilidade. Finalizemos com uma ilustração que nos parece adequada, por resumir um pouco os pontos da nova pauta. No "Prólogo ao teatro" que abre o Fausto ${ }^{40}$ Goethe sintetizou as implicações que esta dualidade acarreta, ao opor o poeta e sua recusa a toda concessão mundana da poesia, ao diretor e ao bufo, um e outro atentos às expectativas do público - mencionado aqui, significativamente, como die Masse. Assim, após a reivindicação do primeiro em endereçar-se apenas a um público ainda inexistente - pois "O que brilha nasceu para o instante/ $\mathrm{O}$ genuíno permanece eterno no mundo-adiante (Nachwelt)" - , e o diretor retruca com esta questão brutal: "Pensai: para quem escreveis?". Cabe ao bufo, ao

mais posso me convencer da legitimidade de minha adesão a ela. Essa conclusão, que não passou despercebida a Cassirer, é preparada por análises morais do século XVII levadas a cabo, dentre outros, por Pascal - "O coração tem razões que a razão desconhece" - e La Bruyère: "De seus pensamentos, compreende-se que o gosto não é exclusivamente a faculdade de juízo da arte, mas um 'modo de sentir' mais geral". (FRANZINI. II gusto in Francia dal Gran Secolo alla Rivoluzione. In: RUSSO (Org.). II gusto Storia di uma idea estetica, p. 37; ver, do mesmo autor, L'estetica del Settecento, p. 99 et seq.).

40 Esse texto, sabe-se hoje, foi redigido por Goethe, tendo em vista, não um drama específico, mas a instituição do teatro em geral - provavelmente, por conta da inauguração do novo Teatro de Weimar, em outubro de 1798 -, e só depois foi anexado à tragédia. Ver, para esse ponto, SCHÖNE, Albrecht. Komentare. In: GOETHE. Faust. v. 2, p. 155. 
discorrer sobre o "ofício poético" (dicht'rischer Geschäfte), a clarividência da nova configuração em que se encontram autor e público, observada por Sartre:

Usai, pois, esses belos dons sem ócio

E organizai o poético negócio

Como no amor uma aventura se prepara.

E a pouco e pouco enleia-se na trama;

Surge a paixão, algo lhe obstrui a chama,

Cresce o êxtase, a dor vem de relance,

E, vede só! Num ai está pronto o romance.

Ponde espetáculo desses em cena!

Inteirai-vos somente da inteira vida humana!

Cada um a vive, em poucos é consciente,

E onde a embrulhais, lá se torna interessante. ${ }^{41}$

\section{Referências}

ALLEN, J. S. In the Public Eye - A History of Reading in Modern France, 1800-1940. Princenton: Princenton University Press, 1991.

BAUMGARTEN, A. G. [1750] Aesthetica. Tradução parcial de Mírian S. Medeiros. In: _. Estética - A lógica da arte do poema. Petrópolis: Vozes, 1993.

CASSIRER, E. [1932] A filosofia do Iluminismo. Tradução de Álvaro Cabral. Campinas: Unicamp, 1992.

. Das Erkenntnisproblem in der Philosophie und Wissenschaft der neueren Zeit. In:_. Gesammelte Werke. Darmstadt: Wissenschaftliche Buchgesellschaft, 1999. v. II.

. [1939] Descartes, Corneille, Christine de Suède. Tradução francesa M. Francès e P. Schrecker. Paris: Vrin, 1997.

. [1944] Ensaio sobre o homem. Tradução de Tomás Rosa Bueno. São Paulo:

Martins Fontes, 1994.

ELIAS, N. La sociedad cortesana. Tradução de G. Hirata. México: FCE, 1996.

FRANZINI, E. Il gusto in Francia dal Gran Secolo alla Rivoluzione. In: RUSSO, L. (Org.). Il gusto - Storia di uma idea estetica. Palermo: Aesthetica Edizioni, 2000.

. L'estetica del Settecento. Bologna: Il Mulino, 2002.

FUMAROLI, M. L'âge de l'éloquence. Paris: Albin Michel, 1994.

GOETHE, J. W. Faust. Darmstadt: WBG, 1999.

HIGHET, G. La tradicion classica - II. México: FCE, 1996.

HORÁCIO. Arte poética. In: ARISTÓTELES; HORÁCIO; LONGINO. A poética clássica. Tradução de Jaime Bruna. São Paulo: Cultrix, 1997.

41 GOETHE. Faust. v. 1, p. 18-19. A tradução sobre a qual introduzimos aqui algumas alterações é de Jenny Klabin Segall. Fausto. Belo Horizonte: Editora Itatiaia, 1987. p. 32. 
HUMPHREYS, A. The Literary Scene. In: FORD, Boris (Ed.) [1957]. The New Pelican Guide to English Literature: From Dryden to Johnson. Londres: Penguin Books, 1997. KANT, I. Crítica da faculdade do juízo. Tradução de Valério Rohden e Antonio Marques. Rio de Janeiro: Forense Universitária, 1993.

MACCHIA, G. Il paradiso della ragione. Torino: Einaldi, 1999.

RACINE, J. Théâtre complet - I. Ed. Jean-Pierre Collinet. Paris: Gallimard, 1995.

SARTRE, J-P. [1948] Qu'est-ce la littérature. Paris: Gallimard, 1967.

WATT, I. [1957] A ascensão do romance. Tradução de Hildegard Feist. São Paulo: Companhia das Letras, 1996.

ZUBER, R. La littérature française du XVII' siècle. Paris: PUF, 1993. 